\title{
Technical Specifications for the Oak Ridge Research Reactor
}




\section{DISCLAIMER}

This report was prepared as an account of work sponsored by an agency of the United States Government. Neither the United States Government nor any agency Thereof, nor any of their employees, makes any warranty, express or implied, or assumes any legal liability or responsibility for the accuracy, completeness, or usefulness of any information, apparatus, product, or process disclosed, or represents that its use would not infringe privately owned rights. Reference herein to any specific commercial product, process, or service by trade name, trademark, manufacturer, or otherwise does not necessarily constitute or imply its endorsement, recommendation, or favoring by the United States Government or any agency thereof. The views and opinions of authors expressed herein do not necessarily state or reflect those of the United States Government or any agency thereof. 


\section{DISCLAIMER}

Portions of this document may be illegible in electronic image products. Images are produced from the best available original document. 
Printed in the I/nited States of Amcrica. Available frum National Technical Information Service

U.S. Department of Commerce 5285 Port Royal Road, Springfield, Virginia 22161

Price: Printed Copy $\$ 5.25$; Microfiche $\$ 3.00$

This report was prepared as an account of work sponsored by an agency of the United States Government. Neither the United States Government nor any agency thereof, nor any of their employees, contractors, subcontractors, or their employees, makes any warranty, express or implied, nor assumes any legal liability or responsibility for any third party's use or the results of such use of any information, apparatus, product or process disclosed in this report, nor represents that its use by such third party would not.infringe privately owned rights. 
Contract No. W-7405-eng-26

Operations Division

TECHNICAL SPECIFICATIONS

FOR THE

OAK RIDGE RESEARCH REACTOR

Operations Division Staff

Date Published - January 1978

This report was prepared as an account of work

sponsored by the United States Government. Neither the

United States nor the United States Department of

Energ, nor any of their employees, nor any of their

contractors, subcontractors, or their employees, makes

any warranty, express or implied, or assumes any tegal
liability of responsibility for the accuracy, completeness

or usefulness of any information, apparatus, product or

process disclosed, or represents that its use would not

infringe privately owned rights.

$-$

OAK RIDGE NATIONAL LABORATORY

Oak Ridge, Tennessee 37830

operated by

UNION CARBIDE CORPORATION

for the

DEPAK'IMENT OF ENERGY 


\section{THIS PAGE}

\section{WAS INTENTIONALLY \\ LEFT BLANK}


CONTENTS

1. Glossary of Terms . . . . . . . . . . . . . . . . 1-1

2. Safety Limits and Limiting Safety System Settings....... . . 2-1

2.1 Safety Limits . . . . . . . . . . . . . . . . 2-1

2.1.2 Safety Limits for Reactor Operation in the Natural

Convection Mode.............. 2-3

2.2 Limiting Safety Syotem Settings (LSSS). . . . . . . . . . 2-4

3. Limiting Cond1tons for Operation . . . . . . . . . . . . . 3-1

3.1 System Reactivity . . . . . . . . . . . . . . 3-1

3.1.1 The Reactor Core... . . . . . . . . . . 3-1

3.2 Core Configuration . . . . . . . . . . . . . . 3-2

3.3 Reactor Control and Safety System . . . . . . . . . 3-3

3.4 Primary Cooling System . . . . . . . . . . . . . 3-6

3.4.1 Power Operation - Forced Flow Mode . . . . . . . 3-6

3.4.2 Startup Operation - Natural Convection Mode . . . . 3-7

3.5 The Facility Cooling System . . . . . . . . . . . . 3-7

3.6 The Reactor Pool System . . . . . . . . . . . . . 3-8

3.7 Gaseous Waste Systems . . . . . . . . . . . . . 3-9

3.8 Emergency Systems . . . . . . . . . . . . . . . 3-10

3.8.1 Confinement System . . . . . . . . . . . 3-10

3.8.2 Emergency Core Cooling ... . . . . . . . . . 3-12

3.8.3 Coolant Leaks . . . . . . . . . . . . . 3-12

3.9 Radiation Monitoring Equipment . . . . . . . . . . . 3-13

3.10 Limitationo on Experimenls . . . . . . . . . . . . . 3-14

4. Survelllance Requirements . . . . . . . . . . . . . . . . 4-1

4.1 System Reactivity . . . . . . . . . . . . . . . 4-1

4.1.1 The Reactor Core .. . . . . . . . . . . . 4-1

4.2 Core Configuration . . . . . . . . . . . . . . . 4-2

4.3 Reactor Control and Safety System . . . . . . . . . . 4-2

4.3.1 Surveillance of Reactor Instrumentation . . . . . 4-3

4.3.2 Mechanical Control System . . . . . . . . . . 4-4

4.4 The Primary Cooling System . . . . . . . . . . . . 4-5

4.4.1 Power Operation - Forced Flow Mode . . . . . . . . 4-5

4.4.2 Natural Convection Mode ............ 4-5 
4.5 The Facility Cooling System . . . . . . . . . . . . 4-6

4.6 The Reactor Pool System . . . . . . . . . . . . . 4-6

4.7 Gaseous Waste Syotems . . . . . . . . . . . . . . . 4-7

4.8 Emergency Systems . . . . . . . . . . . . . . 4-8

4.8.1. Confinement System . . . . . . . . . . 4-8

4.8.2 Emergency Core Cooling . . . . . . . . . . . 4-9

4.8.3 Coolant Leaks . . . . . . . . . . . . . 4-9

4.9 Radiation Monitoring Equipment . . . . . . . . . . . 4-10

4.10 Limitations on Experiments ............... . 4-11

5. Design Features . . . . . . . . . . . . . . . . 5-1

5.1 Reactor Fuel . . . . . . . . . . . . . . . 5-1

5.7 Keaceor Bulldluh . . . . . . . . . . . . . . . b-2

5.3 Fuel Storage and Handling ................. 5-3

6. Administrative Controls . . . . . . . . . . . . . . 6-1

6.1 Organization . . . . . . . . . . . . . . . 6-1

6.2 Personnel Qualification . . . . . . . . . . . . 6-1

6.3 Staff Requirements ................. . . 6-1

6.4 Fac1lity Modifications ................ 61

6.5 Operating Procedures . . . . . . . . . . . . . 6-3

6.6 Action To Be Taken in the Event a Safety Limit

6.7 Act1on To Be Taken in the Event of an Abnormal Occurrence , 6-4

6.8 Reporting Requirements .............. 6-4

6.9 Actions To Be Taken in Regard to Potentlal Degradations
of a Reactor Shutdown System . . . . . . . . . 6-5

6.10 Operating Records . . . . . . . . . . . . . . . 6-6

6.11 Review Committees . . . . . . . . . . . . . . 6-6

6.11.1 Reactor Operations Review Committee . . . . . . 6-8

6.11.2 Reactor Experiment Review Committee . . . . . . 6-7

6.11.3 Cr1ticality Commlttee . . . . . . . . . . 6-7

7. References ................... . 7-1 
TECHNICAL SPECIFICATIONS

FOR THE

OAK RIDGE RESEARCH REACTOR

\section{GLOSSARY OF TERMS}

The following list is a glossary of terms frequently used in the discussions in the Technical Specifications.

1.1 Abnormal Occurrence - An abnormal occurrence is any of the following:

a. Any actual safety system setting less conservative than specified in 2.2, Limiting Safety System Settings.

b. Operation in violation of a Limiting Condition for Operation.

c. Incidents or conditions which prevented or could have prevented the performance of the intended safety function of an engineered safety feature or the reactor safety system.

d. Release of fission products of a magnitude to indicate a failure of the principal physical boundary.

e. An uncontrolled or unantfcipated change in reactivity.

f. An observed inadequacy in the implementation of either administrative or procedural controls, such that the inadequacy has caused the existence or development of an unsafe condition in connection with the operation of the reactor.

g. An uncontrolled or unanticlpated release of radioactivity.

1.2 Calibration - An adjustment of electronic, mechanical, pneumatic, or other sensing systems such as the output of the system responds, with acceptable range and accuracy, to known values of the parameter that the system measures or to known input signals when access to the primary element is limited.

1.3 Certified Operator (RO or SRO) - Any individual who has successfully completed the training, examination, and certification for reactor operator (RO) or senior reactor operator (SRO) pursuant to ERDA Manual Chapter 0540 and pursuant to IAD 8401-6.

1.4 Channel Calibration - A channel calibration is an adjustment of the channel such that its output responds, with acceptable range and accuracy, to known values of the parameter that the channel measures or to known input signals when access to the primary element is limited. 
1.5 Channel Check - A channel check is a qualitative verification of acceptable performance by observation of channel behavior. This verification shall include comparison of the channel with expected values or other independent channels or methods of measuring the same variable.

1.6 Channel Test - A channel test is the introduction of an appropriate signal into a channel to verify that it is operable.

1.7 Core Configuration - The disposition of reactor core elements within the reactor, including pusltion, numbcr, and fuel mass.

1.8 Degradation of the Reactor Shutdown System $=$

a. Class 1 - The actual fallure of the reactor shutdown system to initlate the protective accion whel the reactor variablo has exceeded the limiting safety system setting (LSSS) or the premature termination of the protective action. For example: Reactor coolant flow rate decreases to below the LSSS without an automatic trip; the relatching of neutron-absorbing rods prior to achieving the required shutdown margin.

b. Class 2 - Fallure or malfunction of components, personnel error, or procedural inadequacy which, due to its effect on multiple units, would, by itself, prevent the reactor shutdown system from providing the protective action at the Isss. For example: In a two-out-of-three system, the drift of the setpoints of two flow channels to values beyond the LSSS; an Improper calibration procedure which resulted in several setpoint adfustments being effectively beyond the LSSS.

c. Class 3 - Fallure or malfunction of one or more components, personnel error, or procedural inadequacy which reduces the capability of the reactor shutdown to the extent that the occurrence of a random single failure would prevent the procectlve dition at she LEEE. For example: Tn a two-out-of-three system, the drift of a single channel setpoint to a value beyond the LSSS.

d. Class 4 - Fallure or melfunction of one or morc components, personnel error, or procedural inadequacy affecting a limited number of units such that, although the degree of redundance may be reduced, the reactor shutdown system retains, even after the 
application of the single fallure criterion, the ability to provide the protective action when required (conditions and LSSS) by the Technical Specifications. For example: In a two-out-offour system, one undervoltage relay failed to perform during a test.

1.9 Engineered Safety Features - Features of a unit, other than reactor trip or those used only for normal operation, that are provided to prevent, limit, or mitigate the release of radioactive material.

1.10 Excess Reactivity - Excess reactivity is the excess $k_{\text {eff }}$ above unity that would exist if all the shim-safety rods were fully withdrawn.

1.11 Experiment - An experiment is any apparatus (other than the reactor components and structure), device, or material placed in the reactor core region, in an experimental facility, or in line with a beam of radiation emanating from the reactor.

1.12 Flight Time - Flight time is the time interval between the introduction of a fast scram signal and the actuation of the seat switch of the rod being tested. Flight time measurements are normally made with the rod withdrawn to the upper limlt of its travel.

1.13 Fuel Cycle - This is the period of operation from one refueling to the next refueling. The fuel cycle can vary over a wide range of times usually dependent upon experimental requirements.

1.14 Fuel Element - Fuel elements are core pieces that can be inserted into the ORR grid and that contain a fissionable material for use in the production of energy.

1.15 Ganged-Rod Position - This is a term used to describe the relationship of shim-safety rod positions. Any number of shim-safety rods are said to be at ganged-rod position if they are withdrawn equidistant from their seats.

1.16 Limiting Conditions for Operation - Limiting Conditions for Operation (LCO) are those administratively established constraints required for safe operation of the factlity.

1.17 Limiting Safety System Settings - Limiting Safety System Settings (LSSS) are those limiting values for settings of the safety channels by which point protective action must be inftiated. 
1.18 Movable Experiment - A movable experiment is one in which it is intended that the entire experiment or part of 1 t may be moved in or near the core or into and out of the reactor while the reactor is operating.

1.19 Nominal Full Power - $30 \mathrm{MW}$ (Administrative Limit).

1.20 Operable - A component or system is operable when it is capable of performing its intended function in a normal manner.

1.21 Operating - A component or system is operating when it is performing 1ts Intended function in a normal manner.

1.22 Operating Cycle - The operating cycle is a period of operation, usually seven to nine weeks, at the end of which routine maintenance is usually performed on rejulur components and cxpcriments.

1.23 Operating Modes -

a. Forced Flow Mode - Operation in which forced convection cooling is required; level in excess of $1.2 \mathrm{MW}$.

b. Natural Convection Mode - Operation in which natural convection cooling is adequate; level at $1.2 \mathrm{MW}$ or less.

1.24 Power Operation - Operation at power levels in excess of $1.2 \mathrm{MW}$ (sometimes referred to as "operation at power").

1.25 Reactor Safety System - The reactor safety system is that combination of measuring channels and associated circuitry which forms the automatic protective system of the reactor.

1.26 Reactor Secured - That overall condition where all of the following conditions are satisfied:

a. Reactor shutdown.

b. Electrical power to the control rod circuits is switched off and switch key is in proper custody.

c. No work in progress involving in-core components, experiments, or installed control rod drives.

1.27 Reactor Shut down - The reactor is in a shutdown condition when all shim-safety rods are fully inserted or when it is in a reactivity condition equivalent tu une where all shim aafcty rode are fully inserted.

1.28 Release Time - The release time is the time interval between a fast scram signal and the first detectable movement of the magnet armature. 
1.29 Safety Channel - A safety channel is a combination of detectors, amplifiers and associated circuitry that forms an input to the automatic protective system and is designed to initiate a reactor shutdown for the primary purpose of protecting the reactor.

1.30 Safety Limit - Safety Limits are limits on important process variables which are found to be necessary to reasonably protect the integrity of certain of the physical barriers which guard against the uncontrolled release of radioactivity.

1.31 Shim-Safety Rods - Shim-safety rods (control rods) are the neutronabsorbing core components used to control the reactor power by varying their position in the reactor core. Shim-safety rods may or may not contain a fuel section.

1.32 Shutdown Margin - The shutdown margin is the amount of reactivity which must be added to a shutdown reactor to make 1 t critical.

1.33 Shutdown Mechanisms - The shutdown mechanisms consist of any of the following:

a. Scram - Gravity insertion of all six shim rods.

b. Setback - A reduction of reactor power by the automatic control system.

c. Reverse - Motor driven insertion of all shim rods at their normal insertion speed.

1.34 Specifications for ORR Fuel Elements and/or ORR Shim-Safety Rods Detalled material and fabrication specifications, quality assurance requirements, and associated engineering drawings approved by ORNL Operations Division management.

1.35 Startup Operation - Operation at 1.2 MW or less.

1.36 Time Intervals -

a. Blennially - To be performed once each two years at intervals not to exceed 30 months.

b. Annually - To be performed once each year at intervals not to exceed 14 months.

c. Semiannually - To be performed two times annually at intervals not to exceed 8 months.

d. Quarterly - To be performed four times annually at intervals not to exceed 5 months: 
e. Monthly - To be performed once each month at intervals not to exceed 60 days.

f. Weekly - To be performed once each week at intervals not to exceed 10 days.

g. Dally - To be performed once each day at intervals not to exceed 2 days.

1.37 Tried Experiment - A tried experiment is either of the following:

a. An experiment previously approved and performed in this reactor.

b. An experiment of simllar size, shape, composition, and location as an experiment previously approved and performed in this reactor. 
2. SAFETY LIMITS AND LIMITING SAFETY SYSTEM SETTINGS

\subsection{Safety Limits}

\subsubsection{Safety Limits for Reactor Operation in the Forced Flow Mode} Applicability:

This specification applies to the process variables of Reactor Thermal Power (Q), Reactor Primary Coolant Flow (G), Reactor Coolant Temperature Rise $(\Delta T)$, Reactor Coolant Exit Temperature $\left(T_{e x}\right)$, and the Pressure Drop across the Reactor $(\Delta \mathrm{P})$.

Objective:

The objective is to establish limits for the critical process variables which, if not exceeded, will provide confidence that the integrity of the fuel-element cladding will not be breached.

\section{Specifications:}

When the reactor is operating in the forced flow mode, the following safety limits shall apply:

a. The relationship between the total reactor primary coolant flow rate and the reactor power shall lie under Curve $A$ of Figure 2.1.

b. The reactor coolant temperature rise shall not exceed $32^{\circ} \mathrm{F}$.

c. The reactor core exit temperature shall not exceed $157^{\circ} \mathrm{F}$. Bases:

The safety limits set forth in these specifications have been established to guarantee against operation in a region which can cause damage to the fuel cladding.

The parameters which are of importance in determining the critical heat flux for subcooled boiling burnout are coolant velocity and degree of subcooling. Since none of these parameters can be directly measured, an analysis ${ }^{1}$ of typical ORR cores was undertaken in order to relate parameters to the measured variables, flow, power level, and temperature.

Curve D of Figure 2.1 is a very conservative estimate of the conditions required to produce the critical heat flux somewhere in the core. The safety limits (Curve A) were established by requiring that the minimum subcooling always exceed that required to produce 
ORNL-OWG 77-21319

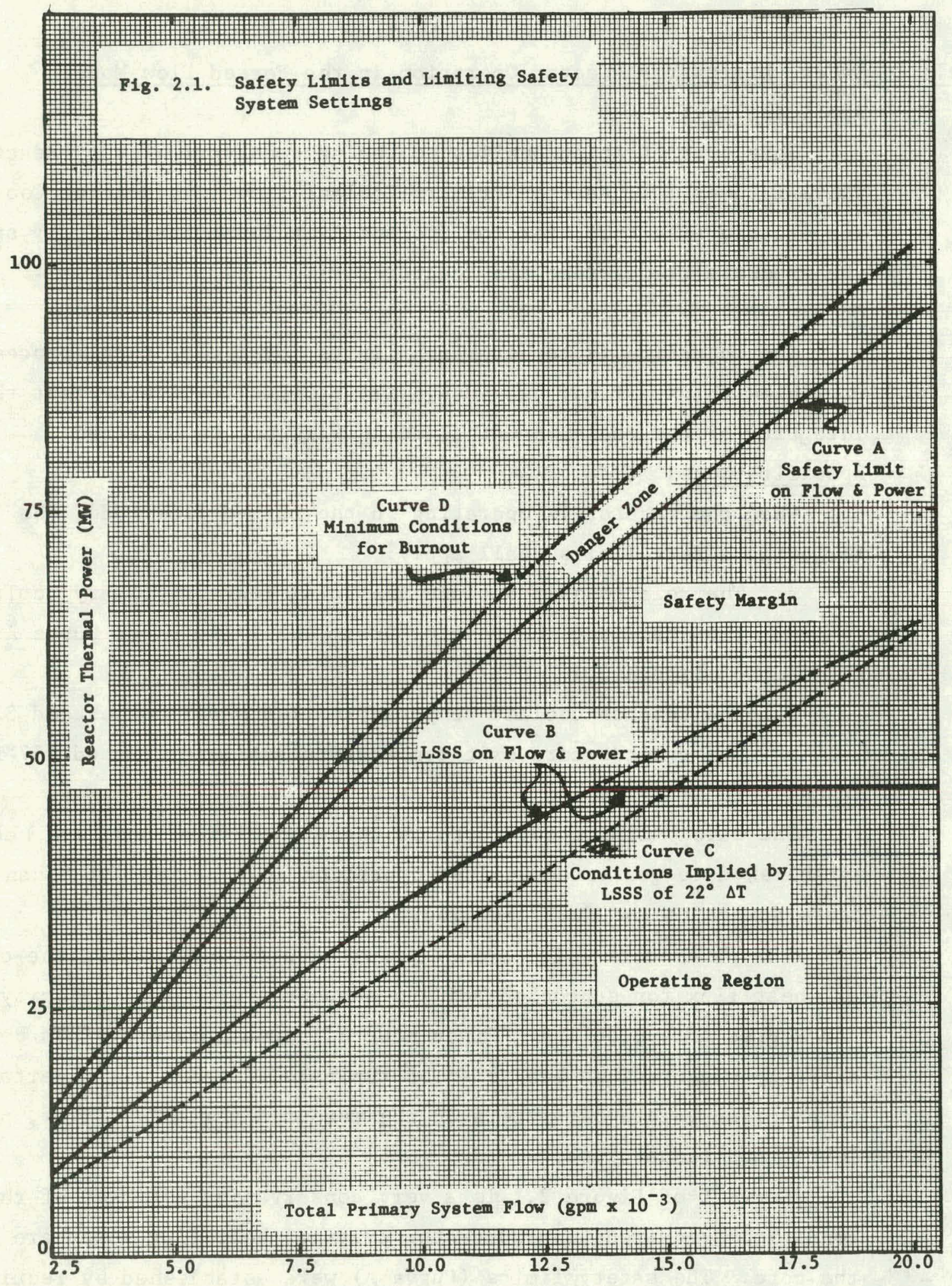


the critical heat flux by an amount sufficient to provide a comfortable margin under the burnout curve as shown in Figure 2.1.

The limftations of $32^{\circ} \mathrm{F}$ for $\Delta \mathrm{T}$ and $157^{\circ} \mathrm{F} \mathrm{T}$ ex are consistent with this requilrement.

2.1.2 Safety Limits for Reactor Operation in the Natural Convection Mode Applicability:

This specification applies to the process variables associated with core thermal hydraulic performance when operating in the natural convection flow mode. These varlables are the Reactor Power ( $Q$ ) and the Primary Reactor Coolant Temperature. Objective:

The objective is to establish limits to the critical process vartables which, if not exceeded, will provide confidence that the integrity of the fuel-element cladding will not be breached.

\section{Spectifications:}

When operating in the natural convection mode, the reactor power shall not exceed $3 \mathrm{MW}$.

Bases:

The safety limits set forth in these specifications have been established to ensure operation at or below a power level, at which point there is a burnout margin greater than 2 .

Bolling experiments performed in the Low Intensity Test Reactor (see References 3 and 4 and pages 69-71 of Reference 5), the core of which was quite simflar to that of the ORR, demonstrated that natural convection cooling constitutes an adequate heat removal mechanism and that the onset of bolling occurs at $1.2 \mathrm{MW}$.

Experiments by W. R. Gambill and R. D. Bundy ${ }^{6}$ lead to the conclusion that the natural convection burnout heat flux of the ORR is $21.25 \times 10^{5} \mathrm{Btu} / \mathrm{ft}^{2} \mathrm{hr}$. At $3 \mathrm{MW}$ the maximum heat flux in the ORR is estimated to be about $5.8 \times 10^{4} \mathrm{Btu} / \mathrm{ft}^{2} \mathrm{hr}$. Hence, the safety limit is a factor of 2.16 below burnout. 


\subsection{Limiting Safety System Settings (LSSS)}

Applicability:

This specification applies to the safety system action setpoints for the reactor process variables related to the safety limits.

Objective:

The objective of this speciflcation is to provide limiting values of the setpoints of the safety channels so that automatic protective action, sufficient to provide confidence that the criteria set forth in the safety limits (Section 2.1) are satisfied, will occur when required. Specifications:

a. For the Forced Flow Mode

(1) Ihe relationship between the total reactor primary coolant flow rate LSSS and the reactor power LSSS shall lie beneath curve $B$ of Figure 2.1 .

(2) In the forced flow mode the total reactor primary coolant flow rate LSSS shall not exceed 22,000 gpm nor shall it be less than $2,500 \mathrm{gpm}$.

(3) The reactor temperature coolant rise LSSS shall not exceed $22^{\circ} \mathrm{F}$.

(4) The reactor coolant exit temperature LSSS shall not exceed $147^{\circ} \mathrm{F}$.

(5) The pressute diup acioss the reaclur correspunds lo llie uperating configuration and the $\triangle P$ LSSS shall correspond to the flow LSSS.

b. For the Natural Convection Mode

Reactor Power: The LSSS on the power of the reactor in the natural convection mode shall be $1.2 \mathrm{MW}$.

Bases:

The limiting safety system settings were chosen such that, when measurement uncertainties and anticipated transient conditions are considered, there is confidence that the criteria set forth in the safety limits are at all times satisfled. The most adverse transient is consldered to be the startup accident ${ }^{8}$ which is less severe when the reactor power and temperature correspond to the LSSS settings than when cold and at zero power, the conditions under which it was evaluated. 
For the forced flow mode the LSSS that have been chosen provide a margin of about 1.6 between the LSSS and the lowest estimated occurrence of a critical heat flux. ${ }^{1}$ In this connection it should be noted that there is a functional relationship between power level, flow, and $\Delta T$ such that if an LSSS associated with one of these variables is exceeded, then at least one of the others is also exceeded. The specific limitations on flow are applied at the lower end to ensure that the limits are within the range of validity of the calculations, and at the upper end to prevent possible structural damage due to excessive hydraulic forces.* The correspondence between flow and pressure drop setpoints are reverified whenever there is a change in core configuration which may significantly affect the flowpressure drop relationship. ${ }^{2}$

The maximum power level LSSS for the natural convection mode has been set at the nucleate boiling level, a factor of 5.4 below burnout and a factor of 2.5 below the safety limit.

Although Section 2.2 specifically addressed forced and natural convection flow, a flow reversal situation can only occur when the reactor is operating at a power level less than $1.2 \mathrm{MW}$. Hence adequate protection is provided.

* Because of its hydraulic characteristics, it is unlikely that the ORR primary coolant system can be operated at flows in excess of $20,000 \mathrm{gpm}$. 


\section{LIMITING CONDITIONS FOR OPERATION}

\subsection{System Reactivity}

Applicability:

These specifications apply to the reactivity condition of the reactor and its assoclated components.

Objective:

The objective is to ensure that the reactor can be made subcritical and maintained in a subcritical condition whenever required, and to prevent the occurrence of any condition that might add a significant amount of uncontrolled reactivity.

\subsubsection{The Reactor Core}

\section{Specifications:}

a. Excess Reactivity Loaded in the Core - The core excess reactivity shall be less than or equal to $50 \%$ of the reactivity worth of the shim-safety rods when they are withdrawn in the ganged position. In addition, the reactor core will be so arranged that the shutdown margin with the highest worth shimsafety rod withdrawn shall be greater than $0.8 \% \Delta \mathrm{k} / \mathrm{k}$ relative to the cold clean condition. The total mass of fuel in the core will be adfusted to achleve this before criticallty for power operation is attained. (Failure to meet these requirements during criticality tests of a new core configuration or for other investigative purposes shall not be regarded as a violation of the specification provided corrective action is taken prior to startup for power operation.)

b. Reactivity Worth of Experiments - The limitations on reactivity worth of experiments either within the core or sufficiently close to the reactor to produce significant interactions are specified in section 3.10 .

\section{Bases:}

a. The limitation on excess reactivity is expressed in terms of relative rod worths rather than in absolute terms, because the absolute worths of the shim-safety rods are a function of the 
specific fuel mass and conflguration of the core. The requirements that no one rod can produce criticality guarantees that the rod worths are distributed in a manner that minimizes the consequences of the uncontrolled withdrawal of a single rod.

To ensure that the worths of the shim-safety rods are adequate to meet the requirements of Section 3.1.1, Specification "a," they are calibrated, individually and ganged, whenever a significant change in core configuration is introduced.

Normally the total worth of the shim-safety rod complement is about $26 \% \Delta \mathrm{k} / \mathrm{k}$ so that the ohutdown margin 1 s about $13 \% \Delta \mathrm{k} / \mathrm{k}$.

b. Reactor experiments are examined to determine their reactivity effects and also their poteitlal fü incieasiny ul decledslug the reactivity of the system; and specific requirements are imposed to ensure that reactor experiments cannot, by fallure or misoperation, significantly affect the reactivity balance of the reactor. This is discussed further in Section 3.10 .

\subsection{Core Configuration}

Applicability:

This specification applies to the determination of core configurations which may be used in the reactor.

Objective:

The objective is to ensure that, under all permissible operating conditions, the maximum heat flux in the reactor is sufficiently below the burnout heat flux to provide an adequate margin of safety.

\section{Specifications:}

The reactor core configuration shall be such that the maximum power generated in any fuel element, as calculated by the methods of Reference 1 , shall not exceed $0.127-0.00159 n$ MW per MW of reactor power where $n$ is the number of core elements, or $0.081 \mathrm{MW}$ per MW of reactor power, whichever is 1ess.

Basis:

At normal flow, $18,500 \mathrm{gpm}$, the burnout heat flux in tixe ORR core has been estimated, using very conservative assumptions, 1 to vary from $1.76 \times 10^{6} \mathrm{Btu} / \mathrm{ft}^{2} \mathrm{hr}$ for a 35 -element core to $2.26 \times 10^{6} \mathrm{Btu} / \mathrm{ft}^{2} \mathrm{hr}$ for a 
25-element core. This specification limits the maximum heat flux under normal operating conditions to $7 \times 10^{5} \mathrm{Btu} / \mathrm{ft}^{2} \mathrm{hr}$ for a $35-e$ lement core and $8 \times 10^{5} \mathrm{Btu} / \mathrm{ft}^{2} \mathrm{hr}$ for cores smaller than 30 elements, thus providing a factor of greater than 2.5 between the normal operating condition and burnout.

Should, at normal power, the reactor coolant flow be reduced to the LSSS value $(13,500 \mathrm{gpm})$, a margin of 2 or more would remain. Should, at normal flow, the power be increased to the LSSS value (47 MW), the margin would exceed 1.6 in all cases. In the worst case where both flow and power reach the LSSS, the margin would.still be at least 1.27 for all the operation conditions permitted by the limitations of Section 2 .

\subsection{Reactor Control and Safety System}

\section{Applicability:}

This specification applies to the safety, control, and surveillance Instrumentation and to the mechanical components of these systems which are required for startup and operation.

Objective:

The objective is to ensure that an adequate complement of safety, control, and surveillance instrumentation together with the requisite mechanical components are available during startup and operation. Specifications:

a. Minimum Reactor Instrumentation Requirements

The minimum complement of reactor safety and.measuring instrumentation required for startup and operation is specified in Table 3.1 . 
Table 3.1. Minimum Instrumentation Required for Reactor Operation

\begin{tabular}{|c|c|c|c|c|}
\hline \multirow[b]{2}{*}{ Description } & & \multicolumn{3}{|c|}{ Number Required } \\
\hline & & $\begin{array}{l}\text { Startup or } \\
\text { Natural } \\
\text { Convection }\end{array}$ & & $\begin{array}{c}\text { Power } \\
\text { Operation }\end{array}$ \\
\hline \multicolumn{5}{|c|}{ Safety or Protective Channels } \\
\hline Safety level channels & & 2 & : & 2 \\
\hline Log N channels & & 1 & & None \\
\hline$\Delta \mathrm{T}$ channels & & None & . & $1 *$ \\
\hline Reactor water exit temperature channels & & "None & & 2 \\
\hline Primargy çoolant flow channels** & & None & & 2 \\
\hline Manual scram & & 1 & & 1 \\
\hline \multicolumn{5}{|c|}{ Measuring Channels } \\
\hline $\mathrm{N}_{16}$ channels & & 1 & & 1 \\
\hline Fission chamber channels & & 1 & & None \\
\hline North facility flow channels & & None & & 1 \\
\hline South facility flow channels & & None & & 2 \\
\hline Normal off-gas vacuum monitor & · & 1 & & 1 \\
\hline Pressurizable off-gas vacuum monitor & . & None & & $1 * * \star$ \\
\hline Building ventilation flow monitor & & 1 & & 1 \\
\hline
\end{tabular}

* $\Delta T$ channels serve as backup instrumentation for the power channels and therefore need not be redundant. **Flow channels may utilize direct flow measurement, or measurement of core $\Delta \mathrm{P}$ using flow calibrated $\Delta \mathrm{P}$ instrumentation. $* * *$ Pressur1zable off-gas monitor is required only if experiments are connnected to the POG system (see page 3-9).

b. Mechanical Contro1 System

(1) Number of Shimisafely Rods - The reactor shall not be operated with less than four shim-safety rods.

(2) Maximum Release Time - The reactor shall not begin an operating cycle unless the release time of the shim-safety rods has been demonstrated to be less than $25 \mathrm{~ms}$.

(3) Maximum Flight Time - The reactor shall not be operated unless the maximum flight time from the upper limit of 
the shim-safety rods under nominal full flow conditions has been demonstrated to be $500 \mathrm{~ms}$ or less or under low flow conditions ( $\leq 2500 \mathrm{gpm}$ ), $1200 \mathrm{~ms}$ or less.

(4) Maximum Rate of Reactivity Addition - The maximum rate of positive reactivity addition (by movement of the shim-safety rods) shall be $11 \mathrm{mited}$ to $0.16 \% \Delta \mathrm{k} / \mathrm{k}$ per second.

(5) Maximum Reactivity Available to the Servo System - The maximum reactivity avallable to the servo-control system shall be 11 mited to $0.75 \% \Delta \mathrm{k} / \mathrm{k}$.

Bases:

The reactor control and safety system is designed to prevent the only credible cause for a massive release of flssion products from the ORR fuel, namely, overheating to an extent sufficient to cause melting and destruction of the integrity of the fuel cladding. Such a condition could be brought about elther by an increase in power beyond the capacity for heat removal, a decrease in the heat transfer capablitty of the system, or a combination of both.

The requirement that the above listed minimum instrumentation be operable and that the assoclated mechanical components be operable is sufficient to guarantee agalnst these conditions.

The consequences of uncontrolled shim-safety rod withdrawals, the so-called "startup" accldent, as well as step additions of reactivity both with and without scram, were investigated under a variety of conditions (see Reference 8, Appendixes $B$ and $C$ ). These include situations in which a scram did not occur but rod withdrawal was stopped when the safety trip point was reached and also situations in which scrams did occur.

The results of these tests indicate that under extremely pessimistic conditions ( 25 ms delay of scram, trip point $183 \%$ of normal. full power, reactivity addition rate at maximum rod worth), with a flight time of $500 \mathrm{~ms}$, the fuel temperature would exceed that corresponding to nucleate boiling, but still not result in burnout.

During normal operation the reactor is operated by means of a servo system which provides automatic shiming-to compensate for small positive and negative reactivity changes. The ORR has a delayed neutron fraction 
equivalent to $20.81 \% \Delta \mathrm{k} / \mathrm{k}$, and the positive reactivity which is available to the servo is maintained at less than this value to prevent the possibility of prompt criticality as a result of servo action.

\subsection{Primary Cooling System}

App1icab111ty:

These specifications apply to the operating conditions of the primary cooling system which provides the heat-removal capacity required to operate the reactor within a safe thermal range.

Objective:

The objective is to ensure that the operating conditions of the primary cooling system remain within the bounds of the system design parameters. 3.4.1 Power Operation - Forced Flow Mode

Specifications:

The reactor shall not be operated at power unless the following conditions are satisfied:

a. The maximum reactor pressure drop does not exceed 38 psi.

b. The primary-coolant outlet temperature does not exceed $147^{\circ} \mathrm{F}$.

c. The primary-coolant flow rate through the reactor vessel lies between $2,500 \mathrm{gpm}$ and $22,000 \mathrm{gpm}$.

Bases:

The design criteria for the reactor vessel and results of the inftial tests prescribe the 1imitation on differential pressure across the reactor.

This maximum is the actual value attained during hydrostatic tests of the vessel.

The bases for the temperature limitation are presented in Section 2.1.1.

Flow rates through the reactor are established to ensure that adequate cooling is avallable on the one hand, and to prevent over stress and deformation of the vessel on the other. The heat transfer requirements are discussed in Section 2.1.1. Tests and evaluations ${ }^{3}$ Indicate that flow rates in excess of $22,000 \mathrm{gpm}$ could lead to locallzed plastic deformation in certain regions of the core struc- 
ture. The low flow value is specified to make certain that the flow is in the turbulent regime where the Bases of Section 2.1.1 apply.

3.4.2 Startup Operation - Natural Convection Mode Specifications:

See Section 2.1.2.

Bases:

See Section 2.1.2.

\subsection{The Facility Cooling System}

Applicab 1lity:

These specifications apply to the operating conditions of the facility cooling system which provides cooling for the north and south engineering test facilities.

Objective:

The objective is to ensure that the operating conditions of the facility cooling system remain within the bounds of the system design parameters.

Specifications:

Power operation of the reactor shall not be permitted unless:

a. The minimum flow through the north engineering test facility 1s $60 \mathrm{gpm}$;

b. The minimum flow through the south engineering test facility 5-ft plug and annulus is $50 \mathrm{gpm}$; and

c. The minimum flow through the south engineering test facility 24-in. annulus is $40 \mathrm{gpm}$.

Bases:

Cooling water to the facllity plugs is provided from the reactor coolant loop of the ORR. Flow is provided by a combination of the pressure drop across the $O R R$ core and factlity cooling pumps. Operation of the facility couling pumps is not critical because about $80 \%$ of normal coolant flow can be provided by the $\Delta P$ across the reactor core with the facility cooling pumps stopped. Deviations below the above flow rates would indicate a malfunction in the ORR primary cooling system. 2,10 


\subsection{The Reactor Pool System}

Applicabil1ty:

These spectfications apply to the conditions that must exist in order that the reactor pool will provide adequate shielding for the reactor core.

Objective:

The objective is to specify minimum water levels in the pool which will provide proper radiation protection to Operations personnel. Specifications:

a. Durlng operation at nominal full power, the reactor pool water level shall be maintalned not less than $13.25 \mathrm{ft}$ above the grating localed al llie reactor tank top (35 ft above the reactor nore midplane).

b. For operation of power levels of $300 \mathrm{~kW}$ or less, the water level in the reactor shall not be lower than the grating at the reactor tank top ( $9 \mathrm{ft}$ above the core centerline); and when necessary, appropriate adminfstrative procedures will be implemented to ensure radiation protection to personnel.

c. For operation at intermediate power levels below normal full power, the pool level may be reduced to an intermediate level for special operations or maintenance provided appropriate administrative procedures to ensure radiation protection of personnel are implemented.

\section{Bases:}

At nominal full power operation the radiation luleusity. directly over the water surface above the reactor is $14 \mathrm{mR} / \mathrm{hr}$ when the pool level is $23 \mathrm{ft}$ above the reactor core centerline. Under the same conditions the radiation level is $9 \mathrm{mR} / \mathrm{hr}$ at the pool parapet nearest the reactor vessel.

For a given power level lowering of the reactor-pool water level increases the radiation level at the pool.surface, and for a given pool water level reduction in the power decreases the radiation level. 'l'hus, administrative controls are provided for off-normal operation to ensure that the radiation-protection requirements of ERDA Manual Chapter 0524 are always met. 


\subsection{Gaseous Waste Systems}

Applicab111ty:

These specifications apply to those systems which are required to remove and dispose of gaseous effluents from the reactor. objective:

The objective is to ensure that sufficient capacity for the removal of gaseous effluents is avallable whenever the reactor is operating. Specifications:

a. Normal Off-Gas System (NOG)

(1) The NOG system shall be in operation and shall be adequate to prevent outleakage at all times whenever one of the following conditions exist:

(a) There are experiments in the reactor which require the use of the NOG.

(b) The reactor is operating at a power in excess of $300 \mathrm{KW}$.

(2) When the NOG is in operation, the vacuum shall be monitored and shall be greater than 15 inches of water.

b. Pressurizable Off-Gas System (POG)

(1) The POG system shall be in operation and shall be adequate to prevent out leakage at all times whenever both of the following conditions exist:

(a) There are experiments in the reactor which require the use of the POG; and

(b) The reactor is operating at a power level in excess of $300 \mathrm{~kW}$.

(2) When the POG is in operation, the vacuum in this system shall be monitored and shall be greater than 15 inches of water.

c. Off-Gas Filters

The gaseous effluent from both the NOG and the POG systems shall, prior to discharge to the atmosphere, pass through a filter system having the following minimum efficiencies:

(1) $99.95 \%$ for particles of diameter greater than or equal to $0.3 \mathrm{microns}$; and

(2) $97 \%$ for elemental lodine. 
Bases:

The NOG system provides for the controlled emission of low volumes of gases generated either in the reactor primary coolant system or in reactor experiments. The POG system is designed to provide for the controlled emission of gaseous effluent from experiments that produce greater than $500 \mathrm{cfm}$ or that have the potentlal to pressurize the waste system. It is necessary that the vacuum in each of these systems be adequate to prevent outleakage from the systems. A power level of $300 \mathrm{~kW}$ is well below that required to cause the evolution of gas sufficiant to necessitate operation of these systems.

After filtration the gases are conveyed to the ORNL 3039 stack where they are combined with effluent from other processes and released at an elevation of $1,064 \mathrm{ft}$. It has been foundl that a continuous release of

$$
1.28 \mu \mathrm{Ci} / \mathrm{s} \text { of lodine }
$$$$
144 \mathrm{mCi} / \mathrm{s} \text { of noble gas }
$$$$
52 \mu \mathrm{Ci} / \mathrm{s} \text { of other mixed fission products }
$$

from this stack will not, on an annual basis, exceed the guidelines of ERDA Manual Chapter 0524 for any of the materials listed.

\subsection{Emergency Systems}

\section{APP11cab1112y:}

These specifications apply to the operating status of those systems that are required to protect the reactor, the operating personnel, and the public should abnormal conditions occur.

\section{Objective:}

The objective is to ensure the operability of the required emergency systems.

\subsubsection{Confinement. Syst.em}

\section{Specifications:}

a. The confinement system shall be operable at all times when the reactor is operating, or during fuel handling operations.

b. The reactor shall not be operated at a power level in excess of $300 \mathrm{~kW}$ if the exhaust from the confinement system to the stack is less than $4,000 \mathrm{cfm}$. 
c. The exhaust from the confinement system passes through a filter system that shall have a minimum efficiency of:

(1) $99.5 \%$ for particulates of diameter greater than 0.3 microns; and

(2) $97 \%$ for elemental lodine.

d. Automatic activation of the contalnment mode of the confinement system shall occur when efther of the following conditions exist:

(1) The general radiation background in the vicinity of the monitor located in the upper half of the reactor bullding exceeds $150 \mathrm{mR} / \mathrm{hr}$; or

(2) The radiation background at the monttor on the building exhaust duct exceeds $50 \mathrm{mR} / \mathrm{hr}$.

e. The reactor shall not be operated at power unless the standby steam-turbine driven blower for the confinement system is operable.

Bases:

The bullding confinement system is an engineered safeguard that provides a physical barrier to prevent the uncontrolled escape of airborne radloactive materlal to the surroundings. 12 The buildIng is maintained at a negative pressure with respect to ambient, and alr flow from it is removed through the ducts, filter, and stack. Since the establishment of a negative pressure differential is related to the exhaust rate, the requirements on exhaust rate have been selected to guarantee an adequate negative pressure. Data collected over a long time period and a wide variety of weather conditions support this selection. 13

The filter efficiencles are based upon the highest values that can be practically achieved with commercial equipment. Many years of experience have shown that these values are more than adequate to reduce the normal effluents to trivial levels, and under the conditions of the maximum hypothetical accident they provide a reduction in the iodine release to well below the maximum permitted by guidelines of 10CFR100.8. 


\subsubsection{Emergency Core Cooling}

\section{Specifications:}

a. The emergency core-cooling system shall be capable of delivering a minimum of $750 \mathrm{gpm}$ through the core for a period of at least 30 minutes without the use of off-site power.

b. A minfmum of two units of the emergency core-cooling system shall be operable at all times when the reactor power exceeds $20 \mathrm{MW}$.

\section{Bases:}

Although tests and calculations (see Reference 8, Appendix B, and Reference 13, page 80), have indicated that forced convection cooling is not necessary during shutdown following operation up to $45 \mathrm{MW}$, the reactor 18 provided with an emergency core-cooling system to provide positive afterheat protection. A battery driven dc motor 1s mounted coaxial with each of the primary coolant pump motors (see Reference 14, Section 6.2). Calculations have shown that with any single dc unit delivering, not its rated capacity of $1,000 \mathrm{gpm}$ but only $500 \mathrm{gpm}$, the maximum fuel plate surface temperature reached following a loss of primary coolant flow and reactor shutdown from $45 \mathrm{MW}$ is about $210^{\circ} \mathrm{F}$ (see Reference 8, Appendix B).

\subsubsection{Coolant Leaks}

\section{Applicability:}

This specification applies to leaks from the primary water cooling system or any auxiliary system connected by pipe to the primary cooling system.

\section{Objective:}

The purpose of this specification is to ensure that the loss of water from the primary cooling system is within acceptable limits.

\section{Specification:}

The reactor shall not be operated with a leak rate in excess of $30 \mathrm{gpm}$.

Basis:

It has been determined ${ }^{7}$ that should a fuel melting accident occur while the reactor coolant system is leaking at a rate of 
$30 \mathrm{gpm}$, even under the most pessimistic assumptions, the consequences would not result in any significant hazard to the public.

\subsection{Radiation Monitoring Equipment}

Applicability

This specification applies to the monitoring of radiation levels and airborne activity in the reactor building.

Objective:

The obfective is to ensure that a sufficient number and variety of. operable instruments to adequately monitor radiation levels throughout the buflding are available.

Specifications:

The reactor shall not be operated unless the following minimum requirements for operable area radiation monitors are met or backup measures approved by the reactor supervisor or his designated alternate are provided:

a. At least three operable constant alr monitors shall be located at approprlate points within the reactor building.

b. At least three operable monitrons shall be located at appropriate points within the bullding.

c. Warnings from the required equipment shall be sounded in the reactor control room.

d. At least one $\beta-\gamma$ stack monitor is operable.

Bases:

The minimum required number of radiation monitors provides protection and warning of elevated levels of radlation so that there will be sufficlent time to evacuate the bullding or portions of the building and to take necessary steps to prevent the spread of radloactivity to the surroundings.

Indication in the control room will warn of excessive radioactivity levels within the building.

The gaseous effluent from the ORR is routed through a stack which serves a number of radiochemical operations as well. Radioactive gaseous effluent is continuously monitored by multiple instrumentation by the Laboratory Facilities Department. Operabllity of the B- $\forall$ monitor is sufficlent to give warning of any abnormal release of activity. 


\subsection{Limitations on Experiments}

Applicability

These specifications apply to all experiments installed in the ORR. Objective:

The objective of these specifications is to establish general limits for ORR experiments that will protect the reactor from damage and shall limit radiation exposure to both on-site and off-site personnel to as low as practicable levels.

\section{Spectfications:}

The following limitations apply to all in-reactor experiments:

a. Reactivity - The following limits apply to individual experiments:

(1) Experiments which can cause a positive reactivity change greater than $0.5 \% \Delta \mathrm{k} / \mathrm{k}$ and which are movable experiments shall be equipped with a mechanical insertion-and-removal system having the same reliabllity as the reactor controlsystem drives. The reactivity insertion rate by these mechanisms shall not exceed $0.025 \% \Delta \mathrm{k} / \mathrm{k} \mathrm{s}^{-1}$.

(2) Experiments which can cause a positive reactivity change greater than $0.5 \% \Delta \mathrm{k} / \mathrm{k}$ due to motion but which need not be moved while the reactor is critlcal shall be so firmly supported that no credible circumstance can cause them to be moved while the reactor is critical.

(3) Experiments which can cause a positive reactivity change greater than $0.5 \% \Delta \mathrm{k} / \mathrm{k}$ due to being damaged by temperature or pressure shall be instrumented to cause an appropriate reactor power or reactivity reduction if such temperature or pressure is approached. This is in addition to the safeguards built into the experiment to control the temperature and/or pressure.

(4) The combined reactivity worth of all experiments which can add positive reactivity to the core due to a common-mode fallure shall be $\mathbf{2 5 0 \%}$ of the ohutdown margin of the shimsafety rod control system. 
b. Hydraulic Stability - All in-tank experiments shall be designed to withstand the hydraulic forces and each assembly shall be staked, welded, or adequately.held to avoid loss into the reactor.

c. Temperature - Heat developed in any experiments by gamma absorption, fissions, electric heaters, etc., shall be dissipated by an adequate coolant flow. Under normal conditions, the temperature of the outer container shall not exceed the saturation temperature of the reactor coolant.

d. Explosives - No explosives or mixtures of material that under credible circumstances can detonate shall be irradiated in the reactor.

e. Pressure Containment - Where fallure of pressure-containing walls of an experiment can cause a hazard to personnel or to the reactor, the container shall meet. the intent of applicable pressure vessel codes. The design for each such container shall be reviewed by a competent engineer and written approval obtained from the Operations Division and the Reactor Experiment Review Committee (RERC).

\section{Bases:}

a. Reactivity

(1), (2), and (3) The upper 1 imit of $0.5 \% \Delta \mathrm{k} / \mathrm{k}$ for a reactivity change by an experiment ensures that such change will not result in prompt criticality. It also ensures that the servo system can Immediately compensate for such change. The limit of $0.025 \% \Delta \mathrm{k} / \mathrm{k} \mathrm{s}^{-1}$ for an intentional, controlled reactivity insertion rate eusures adequate compensation by the servo sys tem.

(4) The restriction on the combined reactivity worth of all experiments guarantees that the shutdown margin is always adequate to make the reactor subcritical.

b. Hydraulic Stability - The reactor components shall be protected from damage that wight result from the movement of an experiment in an uncontrolled manner due to hydraulic forces. Any bolts, nuts, or other 1tems lost from an experiment could conceivably damage reactor components or block coolant flow paths. 
c. Temperature - As with reactor components, the surfaces of experiment rigs are maintalned below the saturation temperature of the reactor coolant to avold steam blanketing and possible burnout.

d. Explosives - The irradiation of explosives is avoided to protect reactor components from possible damage.

e. Pressure Containment - Depending on location, failure of pressurecontaining walls could affect reactivity or damage adjacent reactor components. Fallure of pressure-containing walls external to the reactor may endanger personnel directly by impact infury or release of radioactive gases. The use of applicable pressure vessel codes insures that odequate safety margins. are maintained. 


\section{SURVEILLANCE REQUIREMENTS}

The survelllance requirements in this section apply to continuous system and facility operation. During periods of extended shutdown (periods of time greater than the minimum frequency listed), the stated requirements may be suspended. However, in this case, the requisite survelllance must be performed before the system is again considered operable.

\subsection{System Reactivity}

App11cab111ty:

These specifications apply to the survelllance requirements for system reactivity.

\section{Objective:}

The obfective is to ensure compliance with the specifications in Section 3.1 relative to system reactivity.

\subsubsection{The Reactor Core}

Specifications:

a. Prior to the startup of an operating cycle, the ganged-rod. position that represents $50 \%$ of the shim-safety rod worth shall be determined. If the reactor reaches criticality with the rods withdrawn to a lesser extent than this, the reactor shall be shut down and the situation corrected.*

Prior to the startup of an operating cycle, each shimsafety rod shall be withdrawn to 1 ts upper limit to ensure that the reactor cannot be made critical by the withdrawal of a single rod while the others are fully inserted. (This check is normally accomplished in confunction. with the time-of-flight measurements.) Should.criticality be attained, the reactor shall be shut down and the situation corrected.*

b. When required, calculations shall be performed to ensure that the requirements of Section 3.1.1, Specification " $b$ ", are met. Where uncertainty exists, critical experiments to determine

*See Section 3.1.1. 
the worth of experiments shall be performed. Additional speciflcations concerning experiments are listed in Section 4.10.

c. The shim-safety rods shall be calibrated for reactivity worth annually or whenever a signiflcant change in core loading or experimental load is made.

\subsection{Core Configuration}

\section{Applicability:}

The specifications apply to the procedures for determining permissible core configurations.

\section{Object1ve:}

The objectlve is to ensure compliance with the specifications in Section 3.2 relative to reactor core configuration.

\section{Specif1cation:}

All fuel loadings shall be specified by a qualified member of the Technical Staff and, prior to power operation, all reactor core configurations shall be examined by the Operations Division Technical Staff efther by comparison with previously analyzed cores or by calculallun and/ or experiment to verify that the criterion set forth in Section 3.2 is satisfled.

Basis:

Methods ${ }^{1}$ have been developed to estimate the maximum heat filux in the reactor fuel elements. Moreover, data on the operating power level and maximum heat flux in several hundred core configurations operated in the past are available for comparison.

\subsection{Reaclor Control and Eafety Syetem}

Applicability:

This specification applies to the survelllance requirements for the safety and measuring instrumentation and for the mechanical components of the control systems required for startup and operation. objective:

The objective is to ensure the continued operability of the control and safety systems. 


\subsubsection{Surveillance of Reactor Instrumentation}

a. Testing:

(1) The safety-level channels, the Log-N channel, and the fission chamber channel. shall be tested:

(a) Prior to each startup following refueling or other changes in the reactor core conflguration or a startup following an extended shutdown.

(b) Immediately after any change or maintenance involving any component of these channels

(2) The primary coolant flow channels shall be tested at least quarterly and Imediately after any maintenance or change involving any component of the channels.

(3) The measuring channels as listed in Table 3.1, except for the fission chamber shall be tested:
(a) At least quarterly.
(b) Immediately after any change or maintenance Involving any component of the channels.
(4) The manual scram shall be tested quarterly.

b. Callbration:

(1) The safety or protective channels as listed in Table 3.1, with the exception of the primary coolant flow channel, shall be calibrated at least annually. The primary coolant flow channel shall be calibrated at least biennially.

(2) The measuring channels as 1isted in Table 3.1, except for the flssion chamber channel, shall be calibrated at least biennially. The fission chamber channel shall be calibrated at least annualiy.

(3) Heat balances to check the calibration of instrumentation shall be made dally.

c. Channel Check:

(1) A channel check of those safety or protective channels required during power operation shall be made at least once per shift during reactor operation.

(2) A channel check of those measuring channels required during power operation shall be made prior to each startup follow- 
ing refueling or other changes in reactor core configuration or a startup following an extended shutdown.

(3) A channel check of the north facility flow channels, the south facility flow channels, the normal off-gas vacuum monitor, and the building ventilation flow monitor shall be made at least daily.

\subsubsection{Mechanical Control System}

\section{Specifications:}

a. Prior to the starcup of each uperating cycle and prior to startup following any major maintenance on the shim-safety rods, measurements will be made of the magnet release time and the rod time of flight.

b. The speeds of the shim-safety rod drive motors shall be measured at least annually and following major maintenance on the motors.

c. The reactivity worth of the shim-safety rods and the reactivity available to the servo system shall be determined whenever a significant change in core loading or experiment loading is made. Bases:

Redundance is provided in all safety channels, and monitoring of the power levels by the three safety channels has been provided. Because of this multiple system, random failures have an extremely low probability of feopardizing the ability of these channels to provide their intended purpose. The analysis of 18 years of operational data and maintenance history supports the conclusion that the testing frequency required above is adequate.

Measurement of the drive motor speeds at the specified frequency adequately ensures that reactivity addition rates by the servo control system will not significantly increase as a consequence of changes in drive motor speeds.

Shim-safety rod calibration data have been gathered on a number of occasions during the lifetime of the rods, as well as following each significant change in core configuration. The data Indicate that during the lifetime of a typical rod the composite reactivity worth of all the shim-safety rods is reduced by only $11.5 \%$ of their original valuc. Therefore, recalibration following 
significant changes. In core configuration provides adequate information to predict the shutdown margin at the beginning of each cycle.

\subsection{The Primary Cooling System}

Applicability:

This specification applies to the surveillance requirements of the primary cooling system.

Objective:

The objective is to ensure the continuing integrity of the primary cooling system and to ensure compliance with the speciflcations set forth in Section 3.4 .

4.4.1 Power Operation - Forced Flow Mode

\section{Specifications:}

a. It shall be experimentally determined that the maximum reactor pressure drop cannot exceed 38 psi following any significant change in core loading or experiment loading.

b. Primary-coolant exit temperature shall be under continuous survelllance by at least two instrument channels.

c. It shall be experimentaliy determined that the maximum primary cooling flow. cannot exceed 22,000 gpm following any significant change in core loading or experiment loading.

Bases:

Actual measurement of maximum possible reactor pressure drop and primary coolant flow will ensure compliance with upper limits specified in Section 3.4. Compllance with other specifications set forth in Section 3.4 is ensured through the continuous surveillance of electronic or pneumatic instrumentation as detailed above and in Table 3.1 .

\subsubsection{Natural Convection Mode}

There are no surveillance requirements for the primary cooling system in the natural convection mode. 


\subsection{The Facility Cooling System}

Applicability:

These specifications apply to the survelllance requirements for the operation of the facility cooling system during power operation. Objective:

The objective is to ensure compliance with the specifications set forth in Section 3.5 .

\section{Specifications:}

a. The flow through the north englneerlng test facility shall bc continuously monteored by at least one channel of instrumentation.

h. The flow through the south englneering test facility 5-ft plug and annuluo ohall be continuously mnnttnred by at least one Instrumentation channel.

c. The flow through the south englneering test facility 24-in. annulus shall be continuously monitored by at least one instrumentation channel.

Bases:

Compliance with specifications is ensured through continuous monitoring by the instrumentation specified above.

The operator is warned of decreasing flow rates by appropriate alarms and the reactor power level is automatically reduced when flow rates decrease to the minimum or less.

\subsection{The Reactor Pool System}

Applicahilitiy:

These specifications apply to the surveillance requirements for the reactor pool level (helght of water above core centerline). Objective:

The objective is to ensure compliance with the speclfications set forth in Section 3.6 .

\section{Specifications:}

a. Surveillance of the pool water level shall be made at each reactor startup.

b. Survelllance of the pool water level shall be made daily during reactor operation. 


\section{Bases:}

Water level during normal operation is continuously monitored, and the operator is warned of water loss by both local and control room alarms. Radiation instrumentation would also bring attention to loss of shielding, and other process instrumentation would indicate the change. These indications, coupled with routine water level checks, ensure compliance with the specifications of Section 3.6 .

\subsection{Gaseous Waste Systems}

Applicability:

These specifications apply to the surveillance requirements for the gaseous waste systems.

Objective:

The objective is to ensure proper operation of the systems and to meet specifications set forth in Section 3.7. Specifications:

a. Normal Off-Gas System (NOG)

(1) When the NOG system is in operation:

(a) Checks shall be made prior to each startup to ensure that the system is operating normally.

(b) Pressure drop across the filters shall be measured at least semiannually.

(2) NOG system vacuum shall be under continuous survelilance of at least one instrumentation channel with automatic reduction of reactor power to $\leq 300 \mathrm{~kW}$ should the pressure of the system increase.

b. Pressurizable Off-Gas System (POG)

(1) When the POG system is in operation:

(a) Checks shall be made prior to each startup to ensure that the system is operating normally.

(b) Pressure drop across the filters shall be measured at least semfannually.

(2) POG system vacuum shall be under continuous surveillance of at least one instrumentation channel with automatic reduction of reactor power to $\leq 300 \mathrm{~kW}$ should the pressure of the system Increase. 
c. Off-Gas Filters

The POG and NOG filter system shall be tested for compliance with Section 3.7, Specification "c,".. at least semiannually and prior to reactor startup following filter changes or mafor maintenance.

Bases:

The gaseous removal systems have been in service for 18 years, and the experience indicates that the systems are extremely reliable: Surveillance is needed, however, to protcct against fallure and ensure that a negative pressure sink exists. Based vil operating experienre, it has been determined that the test frequency indicated above is adequate to ensure an operable system. 16

\subsection{Emergency Systems}

Applicab111ty:

These specifications apply to the testing requirements.for those systems that are required to protect the reactor in the event of an abnormal occurrence:

Objective:

The objective is to provide adequate surveillance to ensure the operability of the emergency systems.

\section{8 .1 Conf1nement System}

Specifications:

a. The confinement system shall be successfully tested for operabillty at least semiannually and following any major maintenance on system components.

b. At all times when the reactor is operacing, Llie rate of air exhaust from the bullding shall be monitored.

c. The cunfinement sybteu filterg shall be tested for compliance with Section 3.8.1, Specification "c," semiannually and prior to reactor startup following major maintenance of t1ltèr replacement.

d. A functional test of the system shall be conducted at least semiannually and following major maintenance. This functional test shall include automatic activation of the containment 
mode as specifled in Section 3.8.1.d.

e. The operability of the standby steam turbine shall be verified prior to the start of each operating cycle.

Bases:

The safety limits, speclfied in Section 2, protect the fuel element cladding. Should a release of activity into the building occur, analysis has shown (see Reference 8, Section 6) that the conf1nement system is adequate to prevent a significant release of activity to the environment.

An analysis of the design and performance history indicates that the stated minimum frequencies of testing ensure that the system w1ll be operable. If needed.

\subsubsection{Emergency Core Cooling}

\section{Specifications:}

a. Each pony-motor battery bank shall be checked at least bienially by load testing and monitoring the flow and battery voltage as a function of time.

b. The condition of the batterles that supply power to the emergency core-cooling system shall be checked at least dally when the reactor is operating at power levels above $20 \mathrm{MW}$.

\section{Bases :}

The capacity of alkaline-type batteries, such as the ponymotor battery banks, can be measured only by a load test. Actual operating history Indicates that the specifled surveillance requirements are adequate to ensure the degree of reliability required for the emergency core-cooling system. It should be. recalled (see Secton 3.8.2) that emergency core cooling is not required to protect the fuel cladding.

\subsubsection{Coolant Leaks}

\section{Applicability:}

This specification applies to the survelllance requirements necessary to evaluate leaks from the primary cooling system.

Objective:

The objective is to ensure that leaks from the primary coolant system in excess of those specifled in Section 3.8.3 are detected. 
Specifications:

Unexplained water losses from the primary coolant system shall be determined daily when the reactor is operating.

Basts:

Th1s specification ensures that immediate at tention will be brought to the fact that water losses are occurring and will provide for the implementation of the requirements of specification 3.8.3.

\subsection{Radiation Monitoring Equipment}

Applicab1lity:

This specification applies to the surveillance requirements for the area radiation monftoring equipment.

Objective:

The objective is to ensure that the radiation monitoring equipment is operable.

Speciflcations:

a. A calibration and a test of the radiation monitoring equipment for operability shall be conducted at least semiannually.

b. The stack monltor shall be callbrated at least semiannually, or following maintenance or change involving components of the oyotem.

Bases:

Area radiation monitors are simple radiation detection devices and experience has Indicated that they operate quite reliably for long periods of time. Nevertheless, their tallure at any time culinut be discounted or predicted. Therefore, all the radiation monitors in the planl-wide radiation detection system are continuously monitured electronically to dotect the most common types of fallures expected. These devices are primarily used to detect the presence of radiation where none had previously existed. Their alarm point is set at a small value above background and absolute accuracy is not essential. Hence, the semiannual test for operab1licy combined with the continual electronic monitoring is considered adequate to ensure that the equipment remalns in proper uperation.

.The Indicated frequency of stack monitor calibration has been shown by experience to be adequate to ensure their reliability. 


\subsection{Limitations on Experiments}

Applicability:

This specification applies to the surveillance requirements for experiment limitations.

Objective:

The objective is to ensure compliance with the specifications set forth in Section 3.10 regarding limitations on experiments.

\section{Specifications:}

a. The Technical Assistance Department of the Operations Division shall review and examine all experiments proposed for insertion into the reactor for safety, potential hazards, and compatibility with the operation of the reactor and other experiments.

b. New or unusual experiments shall be submitted with recommendations of the Technical Assistance Department to the Reactor Experiment Review Committee (RERC) for review in accordance with the provisions of Section 6.11 of these Technical Specifications.

c. Tried experiments may be approved by the Technical Assistance Department without further review by the RERC.

\section{Bases :}

Review of experiments in accordance with the above specifications adequately ensures compliance with the specifications set forth in Section 3.10 . 


\section{DESIGN FEATURES}

\subsection{Reactor Fuel}

Applicability:

This specification applies to the fuel elements used in the reactor core.

Objective:

The objective is to ensure that the fuel elements are of such design and are fabricated in such a manner as to permit their use with a high degree of confidence in their reliability with respect to their physical and nuclear characteristics.

Specifications:

a. Reactor Fuel Elements

(1) The fuel elements for the reactor consist of "MTR" platetype elements with cores containing uranium highly enriched in $235 \mathrm{U}$ (see Reference 15). The material requirements shall be as follows:

(a) Fuel plate $\mathrm{U}-\mathrm{Al}$ alloy, $\mathrm{U}_{3} \mathrm{O}_{8}-\mathrm{Al}$ cermet, or $\mathrm{U}-\mathrm{A} 1_{x}$ Intermetallic, Al cladding

(b) $235 \mathrm{U}$ enrichment: up to $97 \%$

(c) Number of plates per element: 10-25

(d) Nominal weight of $235 \mathrm{U}$ per element: $\leq 350 \mathrm{~g}$

(2) Fuel element deslgn and core loading shall be correlated by experiment and calculation to ensure that the maximum operating heat flux will always be below the critical heat flux by a factor of at least 1.6 (see Reference 1).

(3) All fuel elements fabricated for normal use as reactor fuel shall conform to the ORNL. "Specifications for ORR Fuel Elements," and in addition vendors shall develop and implement a quality assurance program equivalent to that spectified in RDT F2-4T. For Internal fabrication the quality assurance program should be equivalent to that spectfied in RDT F2-2T.

(4) Before awarding a contract to fabricate fuel elements, an ORNL site Inspection team must evaluate the prospective vendor's operation and make a positive determination that 
the vendor is capable of producing elements which have an acceptably low probability of fallure in the reactor.

b. Reactor Shim-Safety Rods

(1) The shim-safety rods consist of an upper neutron-absorber section and a lower fuel-follower section, although in some cases the lower section may be of other material such as beryllium or aluminum. 15 The materlal requirements shall be as follows:

(a) Fuel plates: U-A1 alloy, $\mathrm{U}_{3} \mathrm{O}_{8}-\mathrm{Al}$ eermct, or $\mathrm{U}-\mathrm{Al}_{\mathrm{X}}$ Intermetallic, Al cladding

(b) $235 \mathrm{U}$ enrichment: $\quad<97 \%$

(a) Number of plates: $\mathrm{h}-\%$

(d) Nominal weight of $235 \mathrm{U}$ per element: $\leq 250 \mathrm{grams}$

(e) Neutron-absorber: 40-nil thick ld 30-1/2 1n. lung by 2.3 in. square or equivalent

(2) Same as Section 5.1, Specification "a.(2)."

(3) Same as Section 5.1, Specification "a. (3)" except "Specifications for ORR Shim-Safety Rods."

(4) Same as Section 5.1, Specification ". (4)."

Bases:

Calculations during the design and experlence during operation of the reactor indicate that fuel and shlm-safely rods having these characteristics meet the criteria for reliability and performance.

\subsection{Reactor Building}

Applicability:

This specification applies to the bullding that houses the reactor. Objective:

The ubfective is to ensure that provistons atu diale to restrict the amount of airborne radioactivity released to the atmosphere.

\section{Spectifications:}

The reactor is housed in a building designed to be maintained at negative pressure with respect to the outside ambient pressure.

Bases:

The confinement system is designed to exhaust air from the reactor 
building at a rate to ensure leakage into the building and to maintain a slight negative pressure within the building with respect to outside ambient pressure. The air exhausted from the reactor building when in the containment mode passes through a series of filters described in Section 3.8.1 before belng discharged through a stack to the atmosphere. The confinement system is in operation during all modes of reactor operation and during in-pool movement of irradiated fuel.

\subsection{Fuel Storage and Handling}

App11cab1lity:

The specifications apply to the storage and handling of reactor fuel elements and shim-safety rods.

Objective:

The objective is to store and handle fuel in such a manner as to ensure subcriticallty and ensure adequate cooling and shielding of the irradiated fuel.

Spectifications:

a. For Storage and Handling Outside the Reactor Vessel

(1) Fuel elements and/or shim-safety rods shall be stored in storage facilities which have been reviewed, approved, and declared critically safe by ORNL's Criticality Committee. The criterion used is that $K_{\text {eff }}$ shall not exceed 0.95 .

(2) The transfer of fuel elements and/or shim-safety rods between approved storage facilities shall be only by authorization of the reactor supervisor or his authorized representative.

b. For Handling Within the Reactor Vessel

(1) All transfers shall be authorlzed by the reactor supervisor or his authorized representative.

(2) All transfers shall be by written request which provides for identification of all fuel elements handled.

\section{Bases:}

All fuel units used in the ORR are fabricated according to specifications that have been developed to ensure dimensional control to guarantee that the elements will fit into a flxed, nonadjustable grid, to ensure that the fuel content is within rigid limits, to ensure that the cledding will 
safely contain fission products for the life of the elements, and to guarantee structural integrity of the assembled elements.

Stored fuel elements shall be maintalned in a geometry that will prevent criticality. The methods of preventing and/or handling criticality hazards outside of the reactor core must be approved by the ORNL Criticality Committee, and this approval is documented in completed. Nuclear Safety Requests. Critical experiments 17,18 have been performed and these data are used in evaluating requests.

The handling of all fuel elements to, from, and/or within the reactor vessel will result in approved core conflgurations. These core configurations are based on data from bolling experiments, previous fuel loadings, and empirical calculations. All fuel loadings are prepared by lechmical personnel based on these evaluations. 19 


\section{ADMINISTRATIVE CONTROLS}

\subsection{Organfzation}

The Oak Ridge National Laboratory, which is owned by the Department of Energy and operated under contract by the Nuclear Division of Union Carbide Corporation, shall be responsible for operation and supervision of the facility. The Operations Division shall be directly responsible for the operation of the facility. The relationship of the reactor to the Laboratory's structure is shown in Figure 6.1 .

\subsection{Personnel Qualification}

a. The reactor shall be operated by personnel examined and qualified under the general provisions of ERDA Manual Chapter 0540, ERDAM Appendix 8401-II, and IAD 8401-6 and approved by the Operations Division Director.

b. Jobs requiring an operator or a senfor operator qualification are Indicated in Figure 6.1 (Organizational Chart).

\subsection{Staff Requirements}

a. The minimum personnel on duty during reactor operation shall be:

(1) One qualified senior operator; and

(2) One qualified operator.

b. The control room shall be attended by at least one qualified operator at all times during reactor operation.

c. At least one qualifled senior operator shall be present in the control room during reactor startup.

\subsection{Facility Modifications}

a. It shall be the responsibility of the Division Director to ensure that changes in technical specifications or modifications to the plant protection system, reactivity control systems, or engineered safety features, or changes that involve a safety question not reviewed in the safety analysly report shall recelve prior review and authorlzation by the RORC. and/or DOE in accordance with the requirements of ORNL Standard Pract1ce Procedure 18-B and ORO Manual Chapter 0540.

b. Certain mechanical and instrumentation and control design changes may 


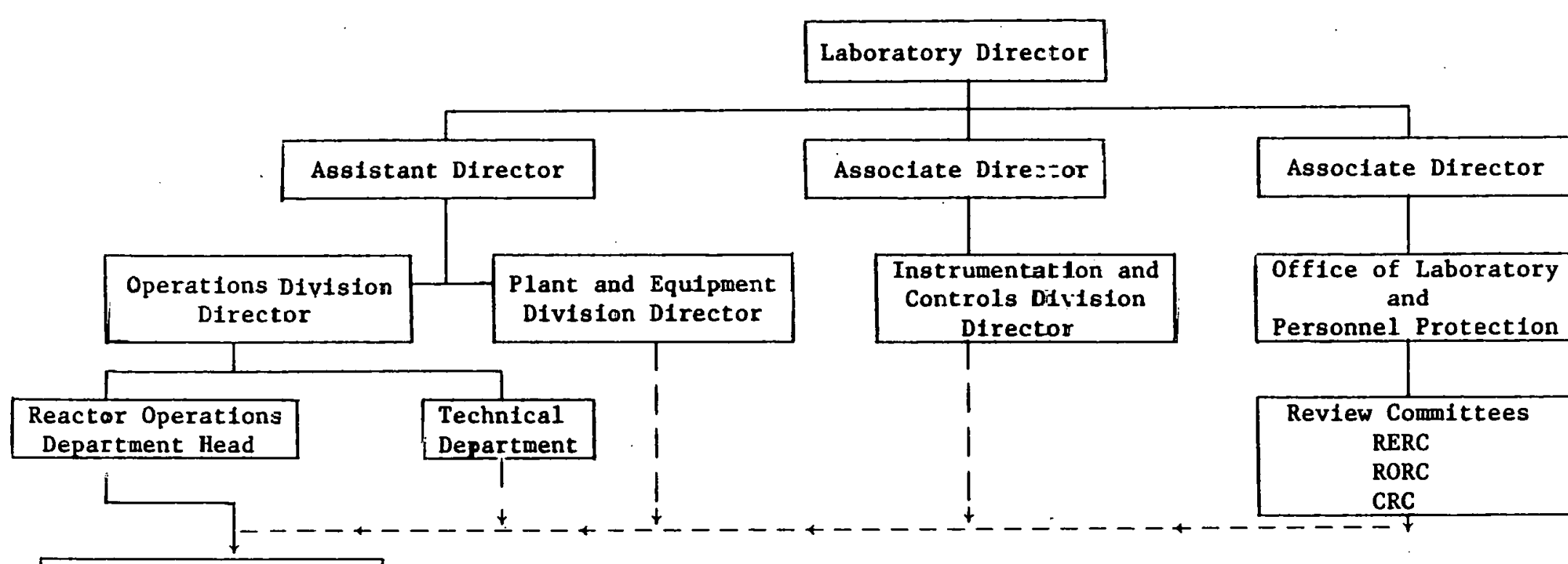

ORR Reactor Supervisor

\section{Assistant Reactor Supervisor ${ }^{1}$}

Assistant Reactor Supervisor

Day Supervisor ${ }^{1}$

Sh1f: Engineers

Reactor Operat:-ss ${ }^{2}$

${ }^{I}$ Shall be certified senior reactor operator.

${ }^{2}$ Shall be certifled reactor operatcr.

Indicates direct line organization

-+-+-+- Indicates direction of support

Figure 6.1. Organizational Chert. 
be made by the contractor provided the effect of the change does not Involve a change in a technical specification or an unreviewed safety question. Formal procedures shall be established for documenting important mechanical and instrumentation and control design changes.

\subsection{Operating Procedures}

a. The reactor shall be operated in accordance with documented operating procedures. In no instance shall the operating procedures designate authorization to operate the reactor outside the bounds of any specifications listed in this document. The procedures shall be adequate to ensure safe operation of the reactor but should not preclude the use of independent judgment and action should the situation require such. Detalled written procedures shall be provided for, but not 11mited to, the following:

(1) Emergency and abnormal conditions including evacuations.

(2) Reactor startup, operation, and shutdown.

(3) Installation and removal of fuel elements, control rods, and all non-permanent reactor components.

(4) Routine maintenance of control rod drives and reactor safety sys tems.

b. A standard method shall be used to change operating procedures as necessary to ensure that all persons concerned are notified of the change and that a permanent record is made. Permanent procedure changes shall require the approval of at least two of the following senior staff members:

(1) Uperations Division Director

(2) Reactor Operations Department Head

(3) ORR Supervisor

(4) Assistant Reactor Supervisor

(5) Day Supervisor

Temporary procedure changes that do not alter their original intent shall be made, when required, by issuing spectal operating instructions. Such speclal operating instructions shall be approved by at least two of the senior staff members listed above. 
c. Radiation control procedures shall be malntained and made avallable to all Operations personnel.

\subsection{Action To Be Taken in the Event a Safety Limit Is Exceeded}

In the event a safety limit is exceeded:

a. The reactor shall be shut down and reactor operation shall not be resumed until authorlzed by DOE.

b. An Immediate report shall be made to the Director of the Office of Laboratory and Personnel Protection.

c. A report shall be made to DOE no later than the next work day.

d. A report shall be made which shall include an analysis of the causes and the extent of possible resultant damage, the effectiveness of correctivè action, and secuimuendationo for mezoures to prevent or reduce the probability of recurrence. This report shall be sent to the Reactor Operations Review Committee (RORC) and a simflar report submitted to DOE when authorization to resume operation of the reactor is sought.

\subsection{Action To Be Taken in the Event of. an Abnormal Occurrence}

In the event of an abnormal occurrence, as defined in Section 1 , the following action shall be taken:

a. The reactor supervisor and other appropriate management persumel shall be notifled and corrective action taken.

b. A report shall be made that shall include an analysis of the cause of the occurrence, efficacy of corrective action, and recommendations for measures to prevent or teduce the probability of recurrence in accordance with ERDA Manual ChapLer 0502.

c. When required, a report shall be submitted to DOE.

\subsection{Reporting Requirements}

a. A report shall be made no lacer llual lie liext worle day to the Safety and Environmental Control Division, DOE, Oak Ridge Operations, of the following conditions:

(1) Any release of radioactivity to the environment above the permissible limits specified in ERDA Manual Chapter 0524. 
(2) Any violation of a safety limit (Section 2.1).

(3) Any exposures to personnel in controlled and uncontrolled areas

that exceed the standards in ERDA Manual Chapter 0524.

b. A report shall be made within three work days to DOE-ORO of any

violation of the Technical Specifications.

\subsection{Actions To Be Taken in Regard to Potential Degradations of a Reactor Shutdown System}

a. Immediate remedial actions required:

(1) Upon experience experiencing a Class 1 degradation of the reactor shutdown system, the ORR shall immediately shut down by manual scram or other emergency backup means that may be necessary.

(2) Upon the discovery of a Class 2 degradation of the reactor shutdown system, the ORR shall immediately be shut down in an orderly (non-emergency) manner, except when the situation warrants more urgent shutdown action.

(3) Upon the discovery of a Class 3 degradation of the reactor shutdown system, ORNL shall take the applicable course of action below:

(a) For coincidence logic system, the degraded unit shall be promptly placed (or kept) in the trlpped state until operability is restored, except for the brief time necessary to determine the operability of the redundant channels. If the action above would result in an automatic scram, this requirement should be satisfied instead by the prompt initiation of an orderly shutdown.

(b) For onc-out-of-two or -lhree systems, where a bypass of a channel for short time periods is authorized in order to permit testing or repalr, the bypassed condition may be retained. If operability cannot be regained by the end of the period authorized for bypass, the reactor shall be immediately shut down in an orderly manner, except when the oituation warrants more urgent shutdown action.

(4) Upon the discovery of a Class 4 degradation of the reactor shutdown system, ORNL shall ascertain the cause of the degradation and implement appropriate corrective action designed to correct 
the specific degradation and to reduce the probability of similar occurrences.

b. Required notification to DOE:

(1) In the event of a Class 1 degradation, ORNL shall verbally notify DOE immediately and provide a written report within five calendar days.

(2) In the event of a Class 2 degradation, the contractor shall verbally notify DOE as expeditiously as practical but within 24 hours and provide a written report within five calendar days.

(3) In the event of a Class 3 degradation, the contractor sliall provide a written report to DOE within five calendar days.

(4) In the event of a Class 4 degradation, the contractor shall include the occurrence in a written repurt to DOE provided no later than 30 days following the occurrence.

c. Authorization for re-startup of the reactor:

Following the occurrence of either a Class 1 or Class 2 degradation of the reactor shutdown system, authorization from DOE is required.

\subsection{Operating Records}

In addition to the requirements of applicable regulations, and in no way substituting therefore, records and logs shall be prepared of at least the following 1 tems and retalned for a perlod of at least flve years:

a. Normal plant uperation

b. Principal maintenance activities

c. Abnormal occurrences

d. Equipment and component surveillance activities required by the Technical Specifications

e. Fuel inventories and transfers

f. Experiments performed with the reactor

g. Updated, corrected, and as-bullt drawings of the facility (chese shall be retained for the lifetime of the facility).

\subsection{Review Committees}

\subsubsection{Reactor Operations Review Comnittee}

There shall be a Reactor Operations Review Committee (RORC) respon- 
sible for periodically conducting an independent safety review of the reactor facility. The members of the RORC shall be appointed by the Director of the Laboratory and shall not be directly involved in the operation of the reactor. The committee members shall collectively possess expertise in all areas of reactor operations and safety.

The RORC shall meet with the operating personnel as frequently as it deems necessary to keep informed of any operational problems or potential hazards. The committee shall conduct at least one formal review each year, and the minutes of this review shall be reported in writing to the Director of the Laboratory. In compliance with the requirements of IAD 8401-7, the RORC shall review any proposed modifications that have safety significance. A detailed description of the committee's function and method of review is presented in Reference 15.

\subsection{1 .2 Reactor Experiment Review Committee}

There shall be a Reactor Experiment Review Committee (RERC) responsible for reviewing any new or unusual experiments proposed for insertion into the reactor. The RERC shall review proposed experiments in such detail as to ensure that no credible fallure or malfunction of the experiment could create a positive change in reactivity greater than the reactor safety system was designed to accommodate. The commlttee shall review experiments from the standpoint of personnel and equipment safety and the continuity of reactor operations. The committee shall, as 1 t deems necessary, place limits upon any materlal, systems, components, effluents, or operations that may present a hazard to personnel or to the reactor. The committee shall, in executing its responsibllity, make recommendations or establish conditions on design, construction, and operation of an experiment. A detailed description of the committee's functions and method of review is presented in Reference 20.

\subsubsection{Criticality Committee}

There shall be a Criticality Committee responsible for the review and approval of operations which involve handling, storage, transportation, and disposal of significant quantities of fissile material. The committee shall on request serve as a consulting group and provide assistance in problems involving criticality. The comittee shall conduct an annual review of all areas containing significant amounts of fissile material to 
ensure that approved procedures are being followed. A detailed description of the commlttee's functions and method of review is presented in Reference 20. 


\section{REFERENCES}

1. F. T. Binford, The Oak Ridge Reactor Safety Analysis, ORNL-4169, Vol. II, Supp. 1, Dec. 1977.

2. Internal Correspondence from T. P. Hamrlck to Distribution, "Flow Measurements in the ORR Core" (October 12, 1976).

3. Internal Correspondence from W. M. Breazeale, T. E. Cole, and J. A. Cox, "Preliminary Boiling Experiments in the LITR" (1953).

4. W. M. Breazeale, T. E. Cole, and J. A. Cox, Further Boiling Experiments in the LITR, AECD-3670 (March 11, 1955).

5. F. T. Binford and C. C. Webster, The Low-Intensity Testing Reactor Safety Analysis, ORNL-TM-1924 (February 1968).

6. W. R. Gambill and R. D. Bundy, Burnout Heat Fluxes for Low-Pressure Water in Natural Circulation, ORNL-3026 (December 20, 1960).

7. Internal Correspondence from F. T. Binford to J. A. Cox, "Significance of Operating with a Leak in the ORR Primary Coolant System," (September 4, 1973).

8. F. T. Binford, The Oak Ridge Research Reactor - Safety Analysis, ORNL-4169, Vo1. II (March 1968).

9. J. M. Corum and B. L. Greenstreet, Thermally Induced Cyclic Strains in the ORR Large-Facizity Dished Heads, ORNL-TM-212 (July 18, 1962).

10. Internal Correspondence from J. Zasler to Distribution, "Interim Design Report--GCR-ORR Loop No. 2" (May 15, 1961).

11. F. T. Binford, T. P. Hamrick, and B. H. Cope, Some Techniques for Estimating the Results of the Emission of Radioactive Effluent from ORNL Stacks, ORNL-TM-3187 (October 1, 1970).

12. F. T. Binford and T. H. J. Burnett, A Method for the Disposal of Volatile Fission Products from on Accident in the Oak Ridge Research Reactor, ORNL-2086 (August 2, 1956).

13. W. H. Tabor and S. S. Hurt, III, Oak Ridge Research Reactor Quarterly Report - January, February, and March of 1969, ORNL-TM-2608 (June 10, 1969).

14. Internal Correspondence from J. A. Cox, "ORR Operations for Period Apr11 1958 to April 1959" (September 10, 1959). 
15. T. P. Hamrick and J. H. Swanks, The Oak Ridge Research Reactor - A Functional Description; ORNL-4169, Vol. I (September 1968).

16. Internal Correspondence from R. Pope and J. J. Smith to Distribution, "In-place Testing of Iodine Filters at ORNL" (November 30, 1972).

17. Internal Correspondence from J. K. Fox and L. W. Gilley, "Critical Experiments with Arrays of ORR and BSF Fuel Elements" (October 2, 1958).

18. E. B. Johnson and R. K. Reedy, Critical Experiments with SPERT-D Fuel Elements, ORNL-TM-1207 (July 14, 1965).

19. Oak Ridge Research Reactor Staff, Operating Monual for the Oak Ridge Resecrch Reactor, ORNL-TM-506 (1962).

20. Intemal Correspondence from D. M. Davis to Distribution, "The Safety Program of Oak Ridge National Laboratory" (May 7, 1975). 




